\title{
Behavior and fluxes of Pt in the macrotidal Gironde Estuary (SW France)
}

Antonio Cobelo-Garcíaํ, Daniel E. López-Sánchez¹, Jörg Schäfer², Jérôme C.J. Petit², Gérard Blanc $^{2}$, Andrew Turner ${ }^{3}$

${ }^{1}$ Instituto de Investigacións Mariñas (IIM-CSIC). Vigo, Galicia, Spain

${ }^{2}$ Université de Bordeaux, UMR EPOC 5805, 33615 Pessac, France

${ }^{3}$ School of Geography, Earth and Environmental Sciences, Plymouth University, UK 


\section{Abstract}

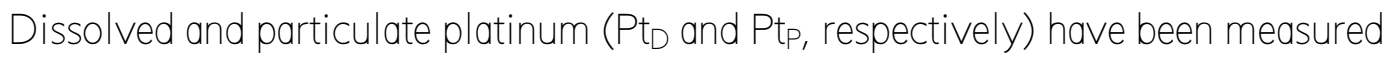
along the salinity gradient in surface water of the Gironde Estuary during two contrasting hydrological regimes; namely, moderate discharge (November 2012) and high discharge (March 2013). During both sets of conditions, PtD concentrations displayed maxima but at different locations along the salinity gradient. These observations are attributed to the addition of Pt from suspended particles traversing the estuary, an effect that is kinetically constrained and sensitive to discharge conditions. A minimum in PtD concentration in the low salinity range observed under high discharge conditions also suggests that Pt removal may occur in the maximum turbidity zone (MTZ). Particulate Pt also exhibited mid-estuarine maxima, an effect attributed to the presence of anthropogenic Pt in this region, but no clear trend for PtP-PtD distribution coefficients was evident during either sampling.

Estimated daily gross dissolved (PtD) and particulate Pt (Ptp) fluxes at La Réole, the main fluvial entry to the Gironde Estuary, were 0.018-0.11 mole day ${ }^{-1}$ (3.6-22 $\mathrm{g} \mathrm{day}^{-1}$ ) and $0.001-0.18$ mole day $^{-1}\left(0.21-35 \mathrm{~g} \mathrm{day}^{-1}\right)$ in November and March, respectively. Using Boyle's method, the daily net PtD fluxes from the Gironde Estuary to the coastal ocean were estimated at 0.03 mole day $^{-1}\left(6.5 \mathrm{~g} \mathrm{day}^{-1}\right)$ for moderate discharge and 0.17 mole day ${ }^{-1}$ (34 $\mathrm{g} \mathrm{day}^{-1}$ ) during high discharge, reflecting the regime-dependent magnitude of Pt remobilisation along the salinity gradient. The findings of the study suggest that estuarine reactivity is of major importance for both the distributions of Pt in estuaries and its export to the global ocean.

Keywords: platinum; reactivity; Gironde Estuary; desorption; fluxes 


\section{Introduction}

Platinum (Pt), one of the most abundant of the Platinum Group Elements (PGE), is amongst the rarest elements in the Earth's crust, with an average concentration of about $2.6 \mathrm{pmol} \mathrm{g}^{-1}$ (or $0.5 \mathrm{ng} \mathrm{g}^{-1}$; Rudnick and Gao, 2003). High chemical resistance and excellent catalytic properties for chemical reactions make Pt an increasingly important component for many technical applications in the chemical, electrical and petroleum industries (J ohnson Matthey 2013). Platinum is also used in catalysts for gasoline and diesel vehicles and is currently being investigated as a potential catalyst in fuel cells of electric cars (APS and MRS 2011). Additionally, Pt is a component of many cytotoxic anticancer drugs due to the capacity of certain Pt complexes to inhibit cell reproduction by interaction with DNA molecules (Remon et al. 2013). The growing use of Pt and the release of a diversity of chemical forms of the metal, including anthropogenic metallic and oxidic nanoparticles emitted from vehicles along roads and anticancer metabolites emitted from hospitals and in the home, make Pt an emerging transition metal contaminant of particular concern (Schäfer et al. 1999; Curtis et al. 2010; Cobelo-García et al. 2011). Forecasts of increasing release into terrestrial and aquatic systems, coupled with long-distance transport to remote and sensitive areas (e.g. Greenland and Antarctic Ice; Barbante et al. 2001; Soyol-Erdene et al. 2011) warrant closer monitoring and a better understanding of the anthropogenic Pt cycle. With respect to the latter, current estimates suggest that around 85\% of the total flux of Pt at the Earth's surface is derived from human activities (Sen and Peucker-Ehrenbrink 2012).

Because urbanized and industrialized areas are hot-spots of Pt use and emission they represent major sources of the metal to the surrounding aquatic environment via run-off and wastewater release (Ravindra et al. 2004). Once emitted to aquatic systems, 
however, little is understood about the transport, behavior and fate of Pt or its compounds. In particular, there is a lack of information on the behavior of Pt in estuaries (e.g. Turner, 2007; Turner and Mascorda, 2014) where the nature, fluxes and concentrations of contaminants are often modified by a variety of chemical and biological reactions. To this end, the present work provides the first measurements of dissolved and particulate Pt for a major European estuary (Gironde, SW France). The data form the basis of both an examination of the partitioning and geochemical behavior of the metal along the salinity gradient and estimates of its flux from land to ocean under different hydrological conditions.

2 Material and Methods

\subsection{Study Area}

The Gironde Estuary, France ( $170 \mathrm{~km}$ length, $\sim 80000 \mathrm{~km}^{2}$ watershed surface area; Fig. 1) is a major European estuary in terms of size and material transport from continent to ocean. Various studies on its physical, hydrological and chemical functioning, including anthropogenically modified trace element cycles, have made it a model fluvial-estuarine system (e.g. Sottolichio and Castaing, 1999, Schäfer et al., 2002). The Gironde Estuary is a meso-to macrotidal estuary and has a mean annual freshwater discharge of $\sim 1000 \mathrm{~m}^{3} \mathrm{~s}^{-1}$. Asymmetrical progression of the tidal wave towards the upstream estuary induces a pronounced maximum turbidity zone (MTZ), with concentrations of suspended particulate matter (SPM) exceeding $1 \mathrm{~g} \mathrm{~L}^{-1}$ in surface water and several hundreds of $\mathrm{g} \mathrm{L}^{-1}$ in bottom water. The MTZ typically resides in the low sal inity region and migrates up and down estuary with seasonal river flow 
variations (Sottolichio and Castaing, 1999). These hydrological and sedimentary features result in typical water and particle residence times of $\sim 20-90$ days and $\sim 1-2$ years, respectively (Castaing and J ouanneau, 1979).

\subsection{Sampling}

River water and SPM samples were collected in January 2013 at the La Réole (the major fluvial entry of the Gironde Estuary; freshwater discharge into the Gironde 2500 $\mathrm{m}^{3} \mathrm{~s}^{-1}$ ) and Port St Marie sites (upstream of the Garonne River and Lot River confluence) in January 2013. The La Réole site integrates material transport from the major of the watersheds and is located in the freshwater reaches upstream of the limit of the dynamic tide (Schäfer et al. 2002). River water and SPM samples (for analyses of dissolved and particulate platinum, PtD and Ptp, respectively) were collected using a telescopic arm fitted with an electric pumping system at $\sim 1 \mathrm{~m}$ from the riverbank and at $\sim 0.2 \mathrm{~m}$ depth; samples were taken after pumping at least $10 \mathrm{~L}$. Water samples were filtered immediately through $0.2 \mathrm{\mu m}$ polycarbonate filters (Nucleopore ${ }^{\circledR}$ ) and filtrates were collected in acid-washed polypropylene (PP) bottles previously rinsed with an aliquot of the filtrate, acidified to $\mathrm{pH}=1(12 \mathrm{M} \mathrm{HCl}$, Baker Instra) and stored in the dark at $4^{\circ} \mathrm{C}$ pending analysis.

Estuarine water and SPM samples were collected along the salinity gradient of the Gironde Estuary during two contrasting freshwater regimes in November 2012 $\left(\sim 410 \mathrm{~m}^{3} \mathrm{~s}^{-1}\right)$ and March $2013\left(\sim 2000 \mathrm{~m}^{3} \mathrm{~s}^{-1}\right)$ onboard the RV "Côtes de la Manche" (INSU). Sampling of surface water (1.5 m depth) was performed with Niskin Bottles, thoroughly rinsed with estuarine water from the site. The sample transfer from the Niskin Bottle into the filtration equipment was performed directly in order to prevent possible sample contamination due to contact with silicone tubing. 
The samples were immediately filtered through pre-weighed cellulose acetate filters (Sartorius ${ }^{\circledR}, 0.2 \mu \mathrm{m}$ porosity). Aliquots for PtD measurements were transferred into $125 \mathrm{ml}$ acid-cleaned PP bottles, acidified to $\mathrm{pH}=1$ (12 $\mathrm{M} \mathrm{HCl}$, Baker Instra) and stored in the dark at $4^{\circ} \mathrm{C}$. The filters containing surface SPM from the estuarine salinity gradient were dried to constant weight $\left(50^{\circ} \mathrm{C}, 48 \mathrm{~h}\right)$, re-weighed and stored in the dark pending digestion and analysis. Samples of bottom SPM (including unconsolidated sediment or fluid mud) were collected along the salinity gradient of the Gironde Estuary during the GIMERCAD (March 2007) cruise using a peristaltic pump with PP-tubing and collected by centrifugation (Westfalia; 12,000 g) as described elsewhere (Schäfer et al., 2002). This technique is considered a practicable and reliable method for representative SPM sampling in all hydrologic situations (Schäfer et al., 2002). The particulate samples were dried $\left(50^{\circ} \mathrm{C}, 48 \mathrm{~h}\right)$, powdered and homogenized with an agate pestle and mortar and stored in sealed PP containers pending digestion and analysis.

\subsection{Freshwater discharge and SPM concentrations}

Fluvial freshwater discharges into the Gironde Estuary are equivalent to the sum of the daily flows in the Garonne and the Dordogne Rivers (Figure 1). The data on daily average freshwater discharges were obtained from the national service responsible for measuring river water discharges in France (HYDRO). Determination of SPM concentrations was performed at all stations by the filtration of precise volumes of river/estuary water through dry, pre-weighed filters (Durrieu glass-fibre, $0.7 \mu \mathrm{m}$ porosity) as described elsewhere (Schäfer et al. 2002). The filters were dried to constant weight at $45^{\circ} \mathrm{C}$, and re-weighed.

\subsection{Dissolved and particulate platinum analyses}


The determination of platinum was achieved by means of catalytic adsorptive cathodic stripping voltammetry as outlined by Van den Berg and J acinto (1988) and using the second derivative signal transformation (Cobelo-Garcia et al. 2014). All laboratory work was performed in a laminar flow bench (ISO-5) housed inside an ISO_7 laboratory. Voltammetric analyses were carried out using a $\mu$ Autolab Type III potentiostat (Metrohm Autoloab BV) connected to a polarographic stand (Metrohm model 663VA) equipped with a hanging mercury drop electrode (HMDE, working electrode), a $\mathrm{Ag} / \mathrm{AgCl}$ (reference electrode) and a glassy carbon rod (counter electrode). A PTFE voltammetric cell was used in all experiments and solutions in the voltammetric cell were stirred using a rotating PTFE rod with the highest rotation speed (3000 rpm) selected. Mercury used was specifically for analysis and polarography (EMSURE ${ }^{\circledR}$, Merck) and the largest drop size possible $\left(0.52 \mathrm{~mm}^{2}\right)$ was employed. The potentiostat was controlled using GPES v.4.9 software (EcoChemie BV).

Procedure for the determination of dissolved Pt. The breakdown of organic matter in the water samples, necessary for the determination of $\mathrm{Pt}_{D}$, was achieved by means of UV oxidation; samples were placed in capped quartz tubes and irradiated for two hours using a 125-W high-pressure mercury lamp placed in a fume hood located inside the ISO-7 laboratory (Cobelo-García et al., 2013). A $10 \mathrm{~mL}$ aliquot of UV-digested sample was pipetted into a Teflon ${ }^{\circledR}$ voltammetric cell. Aliquots of $300 \mu \mathrm{L}$ of $17.7 \mathrm{M} \mathrm{H}_{2} \mathrm{SO}_{4}$ $\left(\geq 95 \%\right.$; TraceSELECT ${ }^{\circledR}$, Fluka), $65 \mu$ L of $1.46 \%$ formaldehyde $(36.5 \%$, Riedel-deHaën) and $95 \mu \mathrm{L}$ of $50 \mathrm{mM}$ hydrazine sulfate (Fluka) (all diluted in Millipore Milli-Q water and stored in $30 \mathrm{~mL}$ PFE Nalgene bottles) were added directly to the sample resulting in final concentrations of the reagents as follows: $0.5 \mathrm{M} \mathrm{H}_{2} \mathrm{SO}_{4}, 3.3 \mathrm{mM}$ 
formaldehyde and $0.45 \mathrm{mM}$ hydrazine. The sample solution was then deaerated by purging with humidified N2 (99.999\%; Alphagaz ${ }^{\text {TM }}$ 1, Air Liquide) for 5 minutes prior to analysis. A new mercury drop was extruded and the potential was set at $-0.3 \vee$ for a deposition time of $300 \mathrm{~s}$ while the solution was stirred at $3000 \mathrm{rpm}$ with the PTFE rod. Stirring was then stopped and, after a quiescence period of $10 \mathrm{~s}$, a stripping scan was performed from $-0.5 \mathrm{~V}$ to $-1.1 \mathrm{~V}$ in the differential pulse (DP) mode at a scan rate of 20 $\mathrm{mV} \mathrm{s}^{-1}$ and using a modulation time of $0.04 \mathrm{~s}$, an interval time of $0.2 \mathrm{~s}$, a modulation amplitude of $25 \mathrm{mV}$ and a step potential of $4 \mathrm{mV}$. The determination of $\mathrm{Pt}$ concentrations was achieved by the method of standard additions using the second derivatives of the voltammetric scans after smoothing the data points according to the Savitsky-Golay algorithm using a smoothing factor of 2 (Cobelo-García et al. 2014).

Procedure for the determination of Pt in SPM and sediments. Suspended particulate matter and sediment samples were ashed in quartz crucibles, and acid-digested using 30 mL screw-capped PFA vials (Savillex) on a time-temperature controlled Teflon-coated hot plate (SFH 5013 HD \& TR 1040 PicoTrace GmbH). Prior to the acid digestion, sediments were ashed at $800^{\circ} \mathrm{C}$ for 3 hours, following the heating scheme given by Nygren et al. (1990), in order to remove refractory organics that may interfere during the voltammetric determination. Ashed SPM and sediments were digested using a mixture of $5 \mathrm{~mL}$ concentrated $\mathrm{HCl}$ and $3 \mathrm{~mL}$ concentrated $\mathrm{HNO}_{3}$ (both Suprapur ${ }^{\circledR}$, Merck) at $195^{\circ} \mathrm{C}$ for 4 hours. Digests were allowed to cool down, caps were removed and the acid was evaporated until near dryness. The residue was then redissolved by adding $1 \mathrm{~mL}$ of concentrated $\mathrm{HCl}$ and $1 \mathrm{~mL}$ of $\mathrm{H}_{2} \mathrm{SO}_{4}$, and heated again until only $\mathrm{H}_{2} \mathrm{SO}_{4}$ was present. Cooled contents were then diluted with $0.1 \mathrm{M} \mathrm{HCl}$, syringe-filtered using a PFA syringe (Savillex) and $25 \mathrm{~mm}$ polyethersulfone membranes of $0.45 \mu \mathrm{m}$ pore size (VWR) and taken up into $25 \mathrm{~mL}$ PP volumetric flasks (Nalgene). The 
voltammetric determination of Ptp in the diluted digests was carried out using the same procedure for water samples but without UV-irradiation.

The detection limit for $\mathrm{Pt}_{\mathrm{D}}$ (expressed as 3sd of blank measurements) was $0.02 \mathrm{pM}$, whereas for Ptp a detection limit of $0.14 \mathrm{pmol} \mathrm{g}^{-1}\left(0.1 \mathrm{ng} \mathrm{g}^{-1}\right)$ was obtained for a typical dry sample mass of $10 \mathrm{mg}$. The relative standard deviation (RSD) of the determination for both PtD and PtD was generally below 10\%. The accuracy of the Ptp determination, checked against digests of river sediment (JSd-2; Geological Survey of J apan) and tunnel dust (BCR-723) certified reference materials, revealed recoveries greater than $80 \%$ and $95 \%$, respectively. Since there is no certified reference material for $P t_{D}$ in water, the accuracy of the voltammetric procedure was evaluated by means of the analysis of spiked river and estuarine waters; recoveries of greater than $95 \%$ were attained by this approach (Cobelo-García et al. 2013).

\subsection{Thorium analyses}

In order to account and correct for potential variations in grain size, chemical normalization of Ptp concentrations were performed with respect to particulate thorium, Thp, an immobile, insoluble element unaffected by anthropogenic inputs (Larrose et al., 2010). Thorium measurements were performed on fine, ground and homogenized samples of sediment and SPM. Between 0.02 and $0.04 \mathrm{~g}$ of precisely weighted aliquots were digested using $3 \mathrm{~mL} \mathrm{HF}$ (suprapur $22 \mathrm{~mol} \mathrm{~L}^{-1}$ ), $1.5 \mathrm{~mL} \mathrm{HCl}$ (suprapur $12 \mathrm{~mol} \mathrm{~L}^{-1}$ )

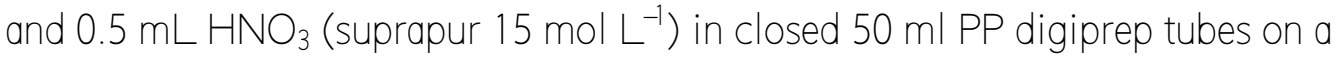
digiprep temperature controlled digestion system for $3 \mathrm{~h}$ at $110^{\circ} \mathrm{C}$. Digests were evaporated to dryness and redissolved in $3 \% \mathrm{HNO}_{3}$ at $65^{\circ} \mathrm{C}$ for 45 min and repeatedly 
ultrasonicated. Thorium analyses were performed by Q_HCPMS (Thermo X7 series II, ThermoScientific). Thorium counts were always higher than 5000 times those of the procedural blanks (digestion and analysis; $0.67 \mathrm{pmol} \mathrm{L}^{-1}$ ), which represented less than $0.05 \%$ of the measured Th concentrations in the samples. Replicate measurements ( $n=$ 2 or 3 ) of several samples always agreed within $5 \%$ rsd. Accuracy was verified with the digestion and analysis of a certified sediment (NCSDC311, certified value of Th $=37$ $\mathrm{nmol} \mathrm{g} \mathrm{g}^{-1}$, returning a concentration of $36 \mathrm{nmol} \mathrm{g}^{-1}$ and corresponding to a recovery of $97 \%$.

\subsection{Flux estimates}

Daily gross $P t_{D}$ and $P t_{P}$ fluxes were estimated by multiplying the respective concentrations in the fluvial Gironde Estuary sampled during January 2013 with daily freshwater discharge and SPM data, as described elsewhere (Lanceleur et al. 2011). Total Pt daily gross fluxes were estimated as the sum of gross PtD and Ptp fluxes.

Daily net fluxes of PtD transferred to the coastal ocean were estimated using Boyle's method; that is, by assuming conservative mixing in the high salinity range and extrapolating the theoretical conservative mixing line over the whole salinity gradient (Boyle et al. 1974).

3 Results

3.1 River discharges and SPM concentrations 
During the November 2012 sampling, the estimated freshwater discharge into the Gironde Estuary was $\sim 410 \mathrm{~m}^{3} \mathrm{~s}^{-1}$ but followed a long lasting ( $\sim 3$ month) period with low freshwater discharges ( $240 \mathrm{~m}^{3} \mathrm{~s}^{-1}$ on average). Suspended particulate matter concentrations ranged from $\sim 20 \mathrm{mg} \mathrm{L}^{-1}$ at salinity $(S)=28$ to $2400 \mathrm{mg} \mathrm{L}^{-1}$ at $S=2$ and in the MTZ. Under these conditions the MTZ was well-developed and restricted to the very low salinity range, as SPM concentrations decreased and remained below values of $<500 \mathrm{mg} \mathrm{L}^{-1}$ at $S \geq 3$ (Figure 2).

During the January and March 2013 sampling, freshwater discharge into the Gironde Estuary was relatively high ( $2500 \mathrm{~m}^{3} \mathrm{~s}^{-1}$ and $2000 \mathrm{~m}^{3} \mathrm{~s}^{-1}$, respectively; Table 1) and SPM concentrations ranged from $85 \mathrm{mg} \mathrm{L}^{-1}(S=22)$ to $850 \mathrm{mg} \mathrm{L}^{-1}(S=0.9)$. By comparison, the freshwater discharge during the March 2007 GIMERCAD cruise, when bottom SPM was sampled, was $2600 \mathrm{~m}^{3} \mathrm{~s}^{-1}$ and the MTZ was well-developed with SPM concentrations in surface water of up to $1600 \mathrm{mg} \mathrm{L}^{-1}$ in the low salinity range and average values of $\sim 300 \mathrm{mg} \mathrm{L}^{-1}$ at $8<S<25$ (Dabrin et al. 2009). Bottom water SPM concentrations were up to $66000 \mathrm{mg} \mathrm{L}^{-1}$ during the GIMERCAD cruise (Table 1), or in the typical 20000 to $100000 \mathrm{mg} \mathrm{L}^{-1}$ range for this region based on observations near/in the fluid mud zone (Robert et al. 2004).

\subsection{Dissolved and particulate Pt concentrations}

The distributions of $\mathrm{Pt}_{D}(<0.2 \mu \mathrm{m})$ and $\mathrm{Pt} P(>0.2 \mu \mathrm{m})$ are shown for the two sampling campaigns in Figure 2. Annotated are the distributions of SPM and, for Pt $t_{D}$, the theoretical dilution line adjoining the river end members and an Atlantic Ocean endmember, based on average measurements of PtD in the North Atlantic Ocean (Colodner 
1991). Also shown in Figure 2 are sediment-water distribution coefficients, $K_{D S}\left(L \mathrm{~kg}^{-}\right.$ $\left.{ }^{1}\right)$, defining the concentration ratios of $\mathrm{Ptp}_{\mathrm{P}}$ to $\mathrm{Pt}_{\mathrm{D}}$ :

$$
K_{D}=\frac{\left[P t_{P}\right]}{\left[P t_{D}\right]} \cdot 10^{3}
$$

Freshwater PtD concentrations (i.e. at $S=0$ ) were 0.53 pM in January 2013; along the salinity gradients, concentrations at the lowest salinities were $0.54 \mathrm{pM}(S=1.2)$ in November 2012 and 0.60 pM (S=0.2) in March 2013. Concentrations of PtD obtained in this study for the Gironde Estuary ranged from 0.35 to 0.84 pM overall, with average ( \pm one sd) values of $0.54 \pm 0.14 \mathrm{pM}(n=15)$ in November 2012 and $0.50 \pm 0.06 \mathrm{pM}(n$ = 11) in March 2013 (Figure 2; Table 1). Minimum PtD concentrations in both profiles were $~ 0.4 \mathrm{pM}$ and maximum PtD concentrations reached $0.84 \mathrm{pM}$ at $S=5$ in November 2012 and 0.62 pM at $S=17$ in March 2013.

Average concentrations of Ptp in SPM were similar on both sampling dates; namely, $3.68 \pm 1.89 \mathrm{pmol} \mathrm{g}^{-1}$ (November 2012) and $3.49 \pm 1.38 \mathrm{pmol} \mathrm{g}^{-1}$ (March 2013). Minimum and maximum Ptp concentrations in SPM were $1.03 \mathrm{pmol} \mathrm{g}^{-1}(S=27.0)$ and $8.97 \mathrm{pmol} \mathrm{g}^{-1}(S=9.9)$ in November 2012, and $1.28 \mathrm{pmol} \mathrm{g}^{-1}(S=0.5-0.9)$ and 5.18 pmol g-1 ( $S=0.2$ ) in March 2013 (Figure 3; Table 1). Platinum concentrations in bottom SPM (Pts) across the salinity gradient during March 2007 ranged from $1.69 \mathrm{pmol}^{-1}$ (S $=0.4)$ to $4.46 \mathrm{pmol} \mathrm{g}^{-1}(S=8.5)$, with an average concentration of $3.03 \pm 0.87 \mathrm{pmol} \mathrm{g}^{-1}$ (Figure 3; Table 1).

Distribution coefficients were very similar during both samplings, averaging $6850 \pm$ $3040 \mathrm{~L} \mathrm{~kg}^{-1}$ and $6950 \pm 3220 \mathrm{~L} \mathrm{~kg}^{-1}$ for November and March, respectively, and with 
respective ranges of 2670 to $13,700 \mathrm{~L} \mathrm{~kg}^{-1}$ and 2640 to $12,000 \mathrm{~L} \mathrm{~kg}^{-1}$. The highest values of $K_{D}$ occurred at $S=9.9$ and 6.3 for the November and March samplings, respectively, while the lowest values occurred at $S \sim 27$ and 0.9 , respectively (Figure 3).

\subsection{Thorium concentrations and Pt enrichment factors}

Average particulate Th concentrations (ThP) were $0.0485 \pm 0.0068 \mu \mathrm{mol} \mathrm{g}^{-1}(n=23)$ and close to its crustal abundance of $0.0453 \pm 0.0043 \mu \mathrm{mol} \mathrm{g}^{-1}$ (Rudnick and Gao, 2003). Particulate Th concentrations in bottom SPM (March 2007) and surface SPM (November 2012 and March 2013) were not significantly different, suggesting a rather constant granularity for all samples.

In order to correct for potential grain size variability on Ptp distributions, concentrations were normalized with respect to Thp and thence to a Th-normal ised baseline

$$
\mathrm{EF}_{\mathrm{Pt}}=\frac{\left(\frac{\mathrm{Pt}_{\mathrm{p}}}{\mathrm{Th}_{\mathrm{P}}}\right)_{\text {sample }}}{\left(\frac{\mathrm{Pt}_{\mathrm{P}}}{\mathrm{Th}_{\mathrm{P}}}\right)_{\text {reference }}}
$$

Here, $E F_{P t}$ is an enrichment factor and the reference in the denominator is based on the crustal abundances of Pt $\left(=2.6 \mathrm{pmol} \mathrm{g}^{-1}\right)$ and Th $\left(=0.0453 \mu \mathrm{mol} \mathrm{g} \mathrm{g}^{-1}\right)$ reported by Rudnick and Gao (2003).

Platinum enrichment factors varied from depleted values $\left(\mathrm{EF}_{\mathrm{Pt}}<1\right)$ of 0.41 to enriched values $\left(E F_{P t}>1\right)$ of 2.41, with an average of $1.18 \pm 0.54(n=22)$. November SPM samples exhibited higher $E_{P t}$ values compared with those of March 2013 and March 2007, with respective averages of $1.58 \pm 0.76(n=6), 0.92 \pm 0.47(n=6)$ and $1.09 \pm$ $0.34(n=9)$. 


\section{Discussion}

\subsection{Comparison of Pt concentrations with those from previous studies}

Platinum in estuaries is derived from both natural and anthropogenic sources. Aqueous forms are derived from the leaching of rocks, waste inputs from hospitals and municipal sewage, and the dissolution of the metal from catalytic converter particulates.

Particulate forms are delivered via weathering of rocks in the catchment, from the input of vehicular catalytic particulates and through the adsorption of aqueous forms to SPM.

The number of studies reporting the concentrations of $\mathrm{Pt}_{\mathrm{D}}$ in natural waters is rather limited, with values ranging from tens of $\mathrm{fmol} \mathrm{L}^{-1}$ to tens of $\mathrm{pmol} \mathrm{L}^{-1}$ (Cobelo-García et al. 2013). For example, a study of $P t_{D}$ distribution in eleven large pristine rivers in East Asia by Soyol-Erdene and Huh (2012), spanning 198 samples returned an overall average concentration of $0.38 \pm 0.13 \mathrm{pM}$ (mean \pm one sd of median values for the eleven rivers). Obata et al. (2006) first reported PtD concentrations in estuarine waters and obtained concentrations in the range of 5 to 35 pM around Tokyo Bay (Japan). Relatively high concentrations were attributed to various anthropogenic emissions within the extensively urbanized area. Considerably lower estuarine concentrations of $P t_{D}(\sim 0.02-0.62 \mathrm{pM}$, with a mean \pm one sd of $0.20 \pm 0.16 \mathrm{pM}$ and $0.09 \pm 0.11 \mathrm{pM}$ for two independent sampling campaigns) were recently reported for a small urban system (Lérez Estuary -Pontevedra Ria) fed by a pristine river in NW Spain (Cobelo-García et al. 2013). Concentrations of PtD obtained in the present study for the Gironde Estuary (ranging from 0.35 to $0.84 \mathrm{pM}$ ) provide further evidence of the typical sub-picomolar Pt concentrations in natural waters that are not extensively perturbed by urbanization. 
Dissolved Pt concentrations along the salinity gradient of the Gironde Estuary are clearly higher than the average North Atlantic value of $0.26 \mathrm{pM}$ (Figure 2); specifically, concentrations of $P t_{D}$ in the river end-member are approximately double the Atlantic end-member value. Thus, while the Gironde does not appear to be extensively contaminated by Pt, the estuary is nevertheless a net source of dissolved Pt to the coastal ocean.

As with the dissolved phase, average Ptp concentrations in surface SPM were similar during both samplings; namely, $3.69 \pm 1.79$ (November 2012) and $3.49 \pm 1.38 \mathrm{pmol} \mathrm{g}^{-1}$ (March 2013). The average crustal Pt abundance is about $2.6 \mathrm{pmol} \mathrm{g}^{-1}$ (PeuckerEhrenbrink and Jahn 2001; Rudnick and Gao 2003) and, consistent with this figure, Ptp background concentrations in estuarine and coastal sediments on the order of 1.5 to 3 pmol g-1 have been reported for Massachusetts Bay USA, (Tuit et al. 2000), and the Tagus Estuary and prodelta, Portugal (Cobelo-García et al. 2011). Average concentrations of Ptp in bottom SPM (3.03 $\left.\pm 0.87 \mathrm{pmol} \mathrm{g}^{-1}\right)$ are slightly lower than the corresponding averages in the SPM and closer to typical crustal-background concentrations.

The only published study reporting Ptp concentrations in estuarine SPM is that of Cobelo-García et al. (2013) for the Lérez Estuary. Here, concentrations of $10.8 \pm 12.3$ pmol g $\mathrm{g}^{-1}(n=15)$ and $41.0 \pm 22.6 \mathrm{pmol} \mathrm{g}^{-1}(n=15)$ were reported for sampling dates during April 2008 and May 2011, respectively. Average Ptp concentrations obtained in the present study for the Gironde Estuary are considerably lower, and, as a consequence of these discrepancies, values of $K_{D}$ are significantly higher in the Lérez, exceeding $10^{5}$ $\left\llcorner\mathrm{kg}^{-1}\right.$ in some cases (Cobelo-García et al. 2013). 
These differences may result from the different turbidities and hydrodynamics in the two systems. Thus, while typical SPM concentrations in the Lérez are no greater than a few mg per liter (generally around $1 \mathrm{mg} \mathrm{L}^{-1}$; Cobelo-García et al. 2013), the Gironde Estuary is highly turbid and SPM concentrations of hundreds of mg per liter are usually present throughout most of its axis. Higher estuarine turbidities are often characterized by systems of greater energy and suspended particles of larger mean diameters than estuaries of low turbidity (Turner and Millward, 2002). Since larger particles have lower surface areas, they have less propensity to adsorb metal ions, including those of $\mathrm{Pt}$, from the aqueous phase. Additionally, because of its urbanized shoreline, the smaller Lérez estuary may contain a higher proportion of Ptp in vehicular catalytic form. Because Pt in this form is relatively insoluble compared with other forms of (e.g. adsorbed) Ptp, the net PtP-PtD partitioning of the metal would be elevated compared with that observed in the Gironde.

\subsection{Ptp enrichment based on Thp normalization}

When the particulate Pt data are normal ized with respect to Th and enrichment factors calculated (equation 2), the values obtained indicate, on average, low to null enrichment in March 2013 surface SPM (EF $\left.F_{P t}=0.92 \pm 0.47 ; n=6\right)$ and March 2007 bottom SPM $\left(E F_{P t}=1.09 \pm 0.34 ; n=9\right)$, and a moderate enrichment in November 2012 estuarine surface SPM (EF $\left.F_{P t}=1.58 \pm 0.76 ; n=6\right)$.

Assuming that particulate Pt in SPM mainly originates from soil erosion and runoff from urban/road surfaces, this observation suggests that during high discharge periods, or periods of high precipitation in the watershed (as in March 2007 and March 2013), 
the Ptp/Thp ratios in SPM from the Gironde Estuary subsurface waters reflect typical watershed signatures. Thus, after long periods of rainfall (i) urban surfaces are likely to have been washed out, conferring a low stock of Pt-rich particles available for runoff, and (ii) intense erosion of soil surfaces in the rural regions of the watershed provides a large flux of particles with baseline catchment signatures (especially in early spring, when the fields are free of intense vegetative cover).

Conversely, in November 2012 and following a long period ( 4 months) of low freshwater discharge into the Gironde Estuary, conditions favor a greater urban signature in the estuary since the relative contribution of fresh urban particles and wastewater to gross fluxes is at maximum (Deycard et al, accepted). The transport of Ptrich particles into the Gironde by runoff during short, small-scale rain events in the Bordeaux urban region and adjacent industrial areas could also explain locally increased Ptp/Thp ratios in SPM. Specifically, the Bec d'Ambes industrial area at the confluence of the Garonne and the Dordogne Rivers (Figure 1) hosts several chemical industries and petrol/gas storage and distribution facilities where Pt may be employed because of its excellent catalytic properties (Johnson-Mattey 2013).

The observed EF pt values in the mid-salinity range of the Gironde Estuary during both November (2012) and March (2013) also allow us to derive a first-order estimate of the relative contributions of natural and anthropogenic particulate Pt in the system. Thus, assuming an average Ptp concentration of $3.0 \mathrm{pmol} \mathrm{g}^{-1}$ in samples without measurable anthropogenic enrichment $\left(0.9<E F_{P t}<1.2\right)$, the $E F_{P t}$ values in the mid-salinity range $(1.8 \pm 0.1)$ suggest that roughly one third of the Ptp $\left(\sim 1.2 \mathrm{pmol} \mathrm{g}^{-1}\right)$ in these samples is of anthropogenic origin. Given that (i) the estimated mass of the SPM stock is $4-5$ million tons, and (ii) average particle residence time in the Gironde Estuary is 1-2 years, 
we estimate that the average anthropogenic particulate Pt contribution to the Gironde Estuary Pt budget is around 2-6 mol $\mathrm{yr}^{-1}\left(400-1200 \mathrm{~g} \mathrm{yr}^{-1}\right)$.

\subsection{Fractionation of Pt in the estuarine water column}

In order to examine, quantitatively, the partitioning and fractionation of Pt in the water column of the Gironde Estuary, the fraction of Pt in the particulate phase was computed as follows (Turner and Millward, 2002):

$$
P t_{P} \text { fraction }=1-\frac{1}{1+K_{D} \cdot S P M / 10^{6}}
$$

The results of the calculations are shown in Figure 4 as a function of SPM concentration and with lines of equal $K_{D}$ annotated for reference. Also shown for comparison are results arising from two surveys undertaken in the Lérez Estuary and as described above (Cobelo-García et al. 2013). In the Gironde, and for both samplings, the fraction of Ptp ranges from about 0.1 to 0.9 , and the data are close to the isopleth of $K_{D}=10^{4} \mathrm{~L} \mathrm{~kg}^{-1}$. This reflects a relatively uniform partitioning of Pt in the estuary, regardless of salinity or hydrological conditions, and indicates that fractionation is governed largely by the concentration of SPM in the water column. In the Lérez Estuary, however, the fraction of Ptp ranges from about 0.02 to 0.7 and the data are more widely distributed over a range of $K_{D S}$ (between about $10^{4}$ and $10^{6} \mathrm{~L} \mathrm{~kg}^{-1}$ ); here, therefore, fractionation is more sensitive to both $K_{D}$ and concentration of SPM. Thus, despite concentrations of SPM that are orders of magnitude greater in the Gironde than in the Lérez, the Ptp fractionation between the two estuaries is not that dissimilar. As suggested above, it is likely that particles in the Lérez are smaller and of higher surface area, resulting in a 
greater propensity for the adsorption of Pt, and contain a higher proportion of relatively unreactive (immobile) catalytic Pt.

\subsection{Estuarine reactivity of Pt and its relation to likely speciation}

The PtD distribution in surface water along the estuarine gradient of the Gironde suggests addition of the metal throughout the estuary during the November sampling but only towards the outer estuary, and removal in the upper estuary during March (Figure 2). These distributions are not accompanied by equivalent and opposite changes in the distributions of Ptp, which shows a bell-shape distribution across the salinity gradient with maximum values and EF $\mathrm{Pt}_{\mathrm{t}}$ at mid salinities and depletion in the low salinity zone (Figure 3). This results in complex distributions of $K_{D}$ with no clear salinity dependence, although highest $K_{D}$ s are consistently found at mid-salinities.

There is only limited thermodynamic information relevant to the speciation of Pt in estuaries (or end-members thereof). Available data suggest that, in sea water, the inorganic equilibrium speciation of $\mathrm{Pt}(\mathrm{II})$ and $\mathrm{Pt}(\mathrm{IV})$ is dominated by $\mathrm{PtCl}_{4}{ }^{2-}$ and $\mathrm{PtCl}_{5}(\mathrm{OH})^{2-}$, respectively (Gammons, 1996), and that, in freshwater, speciation of $\mathrm{Pt}(\mathrm{II})$ and $\mathrm{Pt}(\mathrm{IV})$ is dominated by $\mathrm{Pt}(\mathrm{OH})_{2}$ and $\mathrm{Pt}(\mathrm{OH})_{5}{ }^{-}$, respectively (Kalabina, 1983). Moreover, calculations undertaken by Cobelo-García et al. (2013) indicate that Pt(IV) is the more important oxidation state in sea water, but that Pt(II) is more important in freshwater. Since the relative abundance of the free ion is vanishingly small in aqueous solution (Cosden and Byrne, 2003), interactions of Pt with particulate matter are, therefore, likely to be restricted to negatively charged or neutral complexes. Because the negative charge of the dominant complexes is predicted to increase with increasing salinity and given that SPM bears a net negative charge across the estuarine gradient 
(Loder and Liss, 1985), there will be an increasing repulsion between the SPM surface and Pt species with increasing salinity; in other words, a reduction in Pt adsorption or $K_{D}$ is predicted along the estuarine gradient. This effect has been demonstrated for Pt(IV) by Turner (2007) under laboratory conditions using natural sediment. More specifically, in anticancer drugs, Pt(II) occurs as a series of complexes (cisplatin, carboplatin and oxaliplatin) which are relatively stable when administered in chloride solution, but become highly reactive (as positively charged, aquated metabolites) in an environment of low chloride concentration (i.e. within the cell; Verstraede et al., 2001; Curtis et al., 2010). The metabolites of the drugs, therefore, remain reactive once discharged into fresh water but become progressively less reactive as the chloride concentration (or salinity) of the environment increases. Consequently, and as above, Pt in these forms exhibits a reduction in its tendency to adsorb to suspended particles along the estuarine gradient (Curtis et al., 2010; Turner and Mascorda, 2014).

These descriptions of Pt speciation are partly consistent with the observations on the distributions and partitioning of Pt in the Gironde. Thus, although no clear reduction in $K_{D}$ with salinity is evident, the broad maximum in $\mathrm{Pt}_{\mathrm{D}}$ recorded during November is consistent with remobilisation of the metal from SPM traversing the salinity gradient as species become more negative and less particle-reactive. In March, there is evidence for remobilisation in the lower estuary but removal from the aqueous phase in the upper estuary. In neither survey, however, does the change in PtD reflect an equivalent but opposite change in Ptp, presumably because of the sheer stock of mobile particulate matter in the sedimentary reservoir and the fact that Pt exists in particulate form bound in different forms of differing labilities. 
Clearly, discrepancies between measurements of Pt in the estuary and the speciation considerations above reflect a number of oversimplifications. Thus, firstly we have neglected any interactions of Pt with dissolved or colloidal organic matter. Obata et al. (2006) detected significant fractions of electrochemically-inactive organicallycomplexed Pt species in estuarine waters and these forms have the potential to be flocculated and sedimented from the water column, an effect that is consistent with the minimum in $P t_{D}$ at low salinities that we observed during the March sampling. Secondly, reactions involving Pt are kinetically controlled because of the slow rearrangements of the coordination spheres of Pt(II) and Pt(IV) (Cosden et al., 2003) and this effect is known to constrain the rates of both the complexation and adsorption of aqueous Pt (Turner et al., 2006; Shams et al., 2014). Thirdly, Ptp in catalytic form is relatively unreactive and unlikely to undergo mobilisation readily, and fourthly, we have not considered the potential for benthic fluxes of the metal from tidally disturbed sediment and pore waters. With respect to the latter, previous work on early diagenesis and metal behavior at the sediment-water interface of the Gironde estuary has shown that benthic diffusive metal fluxes are relatively small compared to metal transfer induced by tidally resuspended sediments and/or dredging, and that benthic metals probably equilibrate very efficiently with the abundant the overlying water column (Audry et al. 2007b; Audry et al. 2006; Robert et al. 2004; Audry et al. 2007a).

The differences in Pt distributions and partitioning between the two surveys of the Gironde Estuary may be related to different hydrodynamic regimes and their constraints on Pt reactivity. In March, under high river discharge and the presence of a broad MTZ and when we have inferred a relatively high proportion of non-anthropogenic Pt in the system, the maximum in $P t_{D}$ is relatively small and restricted to the upper half of the 
salinity range. In November, and under moderate river discharge and the presence of a more distinct MTZ in the upper estuary, the maximum in PtD is greater and broader, occurring throughout the estuary. Having reasoned the tendency for different forms of Pt to undergo remobilisation on thermodynamic principles, it is predicted that the extent of desorption is dependent on the concentration of SPM, the amount and nature of Pt held on these particles and the flushing time of the estuary. Given that the concentration of Ptp is similar between the two samplings, the longer flushing times in November (by factors of three to four, as estimated from freshwater discharges according to Castaing and Jouanneau, 1979; November 2012: 70-80 days; March 2013: 20-30 days) allow greater timescales for the remobilisation of Pt within the estuary. During March, remobilisation may occur to the same extent but is likely to be constrained to the outer estuary and into the adjacent coastal zone. Given that aqueous forms of metal are generally more bioavailable than particulate forms to a wider variety of organisms (Kramer, 1994), the region in which remobilisation occurs may have an impact on the types of organism that accumulate Pt. The oyster production areas in the MarennesOléron Bay, for example, may be exposed to greater quantities of Pt during periods of high discharge and short residence times and when Pt-bearing particles are forced further downestuary. Further studies are required to elucidate the extent and impacts of Pt accumulation by estuarine and coastal wild life.

\subsection{Gross and net Pt fluxes}

From the concentrations of Pt in the fresh water end-member sampled in January 2013, total gross Pt fluxes from the watershed into the Gironde Estuary were estimated at 0.02-0.29 mole day ${ }^{-1}$ (3.8-57 $\mathrm{g} \mathrm{day}^{-1}$ ), with gross PtD fluxes ranging from 0.018-0.11 
mole day ${ }^{-1}\left(3.6-22 \mathrm{~g} \mathrm{day}^{-1}\right)$, and gross Ptp fluxes from $0.001-0.18$ mole day $^{-1}(0.21-35 \mathrm{~g}$ day $^{-1}$ ). The net PtD fluxes exported to the coastal Atlantic Ocean during the two sampling campaigns were estimated at 0.03 to 0.17 mole day $^{-1}$ ( 6.5 to $34 \mathrm{~g} \mathrm{day}^{-1}$ ). The removal of PtD observed at low salinities in March 2013 has a minor but not negligible impact on the exported flux, with a decrease of about 10-15\% (5 $\left.\mathrm{g} \mathrm{day}^{-1}\right)$. The overall gross PtD specific yield from the watershed into the Gironde Estuary is estimated to be between 0.023 and $0.14 \times 10^{-5} \mathrm{~mole} \mathrm{~km}^{-2} \mathrm{day}^{-1}$ ( 4.5 to $28 \times 10^{-5} \mathrm{~g} \mathrm{~km}^{-2} \mathrm{day}^{-1}$ ). This estimation compares well with the PtD yield reported for eleven large pristine rivers in East Asia covering mean discharges from 220 to $29,500 \mathrm{~m}^{3} \mathrm{~s}^{-1}$; here, Soyol-Erdene and Huh (2012) obtained a discharge-weighted mean of $0.04 \times 10^{-5} \mathrm{~mole} \mathrm{~km}^{-2} \mathrm{day}^{-1}\left(8 \times 10^{-5}\right.$

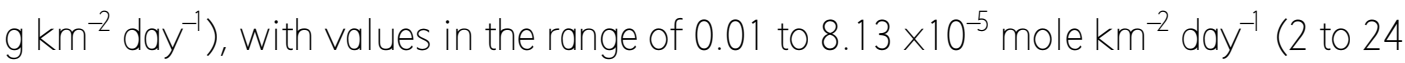
$\times 10^{-5} \mathrm{~g} \mathrm{~km}^{-2} \mathrm{day}^{-1}$ ). Also, values of between 0.015 and $0.077 \times 10^{-5} \mathrm{~mole} \mathrm{~km}^{-2}$ day ${ }^{-1}$ have been estimated from the data of Cobelo-García et al. (2013) for the Lérez Estuary (average discharge of $21 \mathrm{~m}^{3} \mathrm{~s}^{-1}$ ). Although data are unavailable for other world rivers, results presented in this study lend support to a global riverine gross PtD flux into estuaries of $0.036 \times 10^{3}$ mole day $^{-1}\left(7 \times 10^{3} \mathrm{~g}\right.$ day $\left.^{-1}\right)$, obtained assuming a mean global riverine value of $0.36 \mathrm{pM}$ for $\mathrm{Pt}_{\mathrm{D}}$ and a global river runoff of $1025 \times 10^{8} \mathrm{~m}^{3}$ day $^{-1}$ (Soyol-Erdene and Huh 2012).

The non-conservative behavior of PtD in the present study, with net addition over a range of salinities, results in an enhanced export of Pt to the Atlantic Ocean waters relative to the input of PtD via rivers. Accordingly, the calculated net specific PtD fluxes from the Gironde Estuary to the ocean are between 0.04 and $0.22 \times 10^{-5} \mathrm{~mole} \mathrm{~km}^{-2} \mathrm{day}^{-1}$ (8 to $42 \times 10^{-5} \mathrm{~g} \mathrm{~km}^{-2} \mathrm{day}^{-1}$ ), or roughly double the gross $\mathrm{Pt}_{\mathrm{D}}$ flux from the watershed. The estuarine remobilisation of $\mathrm{Pt}_{D}$ has important implications for the estimation of the Pt oceanic budget and its residence time. For example, an oceanic residence time of 24 
$\times 10^{3}$ years was derived by Soyol-Erdene and Huh (2012) assuming no release or uptake of PtD in estuaries; the authors indicated, however, that a 50\% release in estuaries would modify this value to $16 \times 10^{3}$ years. Based on the observations of the present study in the Gironde Estuary, the latter value would appear to be a more accurate estimate.

\section{Conclusions and perspectives}

This work provides the first measurements and flux estimates of PtD and Ptp for a major European estuary. Overall concentrations of $P t_{D}$ and Ptp ranged from 0.35 to $0.84 \mathrm{pM}$ and from 1.02 to $8.97 \mathrm{pmol} \mathrm{g}^{-1}$, respectively. The behavior of PtD during estuarine mixing was non-conservative during two sampling campaigns, with minimum concentrations observed in the low salinity range on one occasion and net addition over a range of salinities observed during both campaigns. Addition was attributed to the thermodynamic drive for the remobilization of various forms of Pt from suspended particles traversing the salinity gradient. The gross PtD yield from the watershed into the Gironde Estuary agrees well with values reported for other world rivers, and reinforces current estimates of the global riverine Pt flux to estuaries. The net PtD addition on estuarine mixing results in a 2 fold increase in the export of Pt to the ocean compared with the riverine input, with consequent implications for estimates of the Pt oceanic mass balance and residence time. More data for a wider range of systems, including both pristine environments and estuaries whose catchments are intensively urbanized, are needed to verify whether the behavior of Pt observed in the Gironde is a general trait. 
Although our understanding of the biogeochemical behaviour of Pt in the marine environment has advanced in the past decade, there are still a number of issues that have not been adequately addressed. These include the determination of the mobility and bioavailability of particle-bound Pt in estuaries, an estimation of Pt fluxes prior to the introduction of catalytic converters through the analysis of SPM sample archives and/or sediment cores, and measurement of the bioaccumulation of Pt in estuarine biota used for human consumption (e.g. oysters, cockles). Moreover, no field studies have been carried out thus far on the estuarine behavior of the other PGE: Pd and Rh. As with Pt, these elements are present in catalytic converters and their fluxes at the Earth's surface are also dominated by human activities (Sen and Peucker-Ehrenbrink 2012). Given the perturbation of their geochemical cycles and their relatively high bioavailability observed in terrestrial systems (especially Pd; Schäfer et al. 1998), further studies on these metals are called for.

\author{
Acknowledgements \\ The CSIC, under the program JAE-PreDoc (Junta para la Ampliación de Estudios) co- \\ funded by the Fondo Social Europeo (FSE), is greatly acknowledged for the predoctoral \\ fellowship to D.E. López-Sánchez. Jérôme C.J. Petitwas funded by the Marie Curie \\ Individual Fellowship FP7-PEOPLE-2011 - IEF \#302505 ISOGIRE. The authors also \\ acknowledge Susana Calvo (IIM-CSIC) for technical support, and the captain and crew \\ members of the RV "Côtes de la Manche" (INSU), and support from INSU and \\ CIRMAT.
}


References

APS and MRS, 2011. Energy Critical Elements: Securing Materials for Emerging Technologies. www.aps.org/policy/reports/popa-reports/upload/elementsreport.pdf Audry, S., Blanc G., Schäfer J., Robert S., 2006. Early diagenesis of trace metals (Cd, $\mathrm{Cu}, \mathrm{Co}, \mathrm{Ni}, \mathrm{U}, \mathrm{Mo}$ and $\mathrm{V}$ ) in the freshwater reaches of a macrotidal estuary. Geochimica et Cosmochimica Acta 70, 2264-2282

Audry S., Blanc G., Schäfer J., Guérin F., Masson M., Robert S. 2007a. Budgets of Mn, $\mathrm{Cd}$ and $\mathrm{Cu}$ in the macrotidal Gironde estuary (SW France). Marine Chemistry 107, $433-448$.

Audry S., Blanc G., Schäfer J., Robert S. 2007b. Effect of estuarine sediment resuspension on early diagenesis, sulfide oxidation and dissolved molybdenum and uranium distribution. Chemical Geology 238, 149-167.

Barbante, C., Veysseyre, A., Ferrari, C., van de Velde, K., Morel, C., Capodaglio, G., Cescon, P., Scarponi, G., Boutron, C., 2001. Greenland snow evidence of large scale atmospheric contamination for platinum, palladium, and rhodium. Environmental Science and Technology 35, 835-839.

Boyle, E.A., Collier, R., Dengler, A.T., Edmond, J.M., Ng, A.C., Stallard, R.F., 1974. On the chemical mass-balance in estuaries. Geochimica Cosmochimica Acta 38, 1719 1728.

Castaing, P., Jouanneau, J.M., 1979. Temps de résidence des eaux et des suspensions dans l'estuaire de la Gironde. Journal de Recherche en Océanographie, 41-52.

Cobelo-García, A., Neira, P., Mil-Homens, M., Caetano, M., 2011. Evaluation of the contamination of platinum in estuarine and coastal sediments (Tagus Estuary and Prodelta). Marine Pollution Bulletin 62, 646-650.

Cobelo-García, A., López-Sánchez, D.E., Almécija, C., Santos-Echeandía, J., 2013. Behavior of platinum during estuarine mixing (Pontevedra Ria, NW Iberian Peninsula). Marine Chemistry 150, 11-18.

Cobelo-García, A., Santos-Echeandía, J., López-Sánchez, D.E., Almécija, C.,

Omanović, D., 2014. Improving the voltammetric quantification of ill-defined peaks using second derivative signal transformation: example of the determination of platinum in water and sediments. Analytical Chemistry 86, 2308-2313. 
Colodner, D., 1991. The Marine Geochemistry of Rhenium, Iridium and Platinum. PhD Thesis, Massachusetts Institute of Technology.

Cosden, J.M., Byrne, R.H., 2003. Comparative geochemistries of Pdll and Ptll: formation of mixed hydroxychloro-and chlorocarbonato-complexes in seawater. Geochimica et Cosmochimica Acta 67, 1331-1338.

Cosden, J.M., Schijf, J., Byrne, R.H., 2003. Fractionation of platinum group elements in aqueous systems: comparative kinetics of palladium and platinum removal from seawater by Ulva lactuca L. Environmental Science and Technology 37, 555-560. Curtis, L., Turner, A., Vyas, N., Sewell, G., 2010. Speciation and reactivity of cisplatin in river water and seawater. Environmental Science and Technology 44, 3345-3350. Dabrin, A., Schafer, J., Blanc, G., Strady, E., Masson, M., Bossy, C., Castelle, S., Girardot, N., Coynel, A., 2009. Improving estuarine net flux estimates for dissolved cadmium export at the annual timescale: application to the Gironde Estuary, Estuarine, Coastal and Shelf Science 84, 429-439.

Gammons, C.H., 1996. Experimental investigations of the hydrothermal geochemistry of platinum and palladium: V. Equilibria between platinum metal, Pt(II), and Pt(IV) chloride complexes at 25 to $300^{\circ} \mathrm{C}$. Geochimica et Cosmochimica Acta 60, 1683-1694. HYDRO; Ministère de l'Ecologie et du Développement Durable; BANQUE HYDRO; http://www.hydro.eaufrance.fr.

Johnson Mattey 2013. Platinum 2013 Interim Review. http://www.platinum.matthey.com/media/1631235/platinum_2013_interim_review.pdf Kalabina, L.V., 1983. Mononuclear hydroxo complexes of platinum(IV). Ukrainskii Khimicheskii Zhurnal 49, 342-345.

Kramer, K.J.M. (ed), 1994. Biomonitoring of Coastal Waters and Estuaries. CRC Press, Boca Raton, FL.

Lanceleur L., Schäfer J., Coynel A., Bossy C., Blanc G. (2011). Dissolved and particulate silver transport at the watershed scale - anthropogenic component and fluxes into the Gironde Estuary (1999-2009). Applied Geochem. 26, 797-808.

Larrose A., Coynel A., Schäfer, J., Masse, L., Maneux, E., Blanc, G. (2010). Assessing the current state of a major European estuary by mapping priority contaminant distribution and risk potential in surface sediment. Applied Geochem. 25, 1912-1923.

Loder, T.C., Liss, P.S., 1985. Control by organic coatings of the surface-charge of estuarine suspended particles. Limnology and Oceanography 30, 418-421. 
Nygren, O., Vaughan, G.T., Florence, T.M., Morrison, G.M.P., Warner, I.M., Dale, L.S., 1990. Determination of platinum in blood by adsorptive voltammetry. Analytical Chemistry 62, 1637-1640.

Obata, H., Yoshida, T., Ogawa, H., 2006. Determination of picomolar levels of platinum in estuarine waters: a comparison of cathodic stripping voltammetry and isotope dilution-inductively coupled plasma mass spectrometry. Analytica Chimica Acta 580, 32-38.

Peucker-Ehrenbrink, B., Jahn, B., 2001. Rhenium-osmium isotope systematic and platinum group element concentrations: Loess and the upper continental crust. Geochemistry Geophysics Geosystems 2, 2001GC000172.

Ravindra, K., Bencs, L., Van Grieken, R., 2004. Platinum group elements in the environment and their health risk. Science of the Total Environment 318, 1-43.

Remon, J., Lianes, P., Martínez, S., Velasco, M., Querol, R., Zanui, M., 2013. Adjuvant treatment in resected non-small cell lung cancer: Current and future issues. Critical Reviews in Oncology/Hematology 88, 375-386.

Robert S., Blanc G., Schäfer J., Lavaux G., Abril G. (2004). Metal mobilization in the Gironde estuary (France). The role of the soft mud layer in the maximum turbidity zone. Marine Chemistry 87, 1-13.

Rudnick, R.L., Gao, S., 2003. Composition of the continental crust. In: Holland, H.D., Turekian, K.K. (Eds.), Treatise on Geochemistry, vol. 3. Elsevier, pp. 1-64.

Schäfer, J., Hannker, D., Eckhardt, J.D., Stüben, D., 1998. Uptake of traffic-related heavy metals and Platinum Group Elements (PGE) by plants. Sci. Total Environ. 215, $59-67$.

Schäfer, J., Eckhardt, J.D., Berner, Z., Stüben, D., 1999. Time-dependent development of traffic-emitted Platinum Group Metals (PGM) in different environmental compartments. Environ. Sci. Technol. 33, 3166-3170.

Schäfer J., Blanc G., Lapaquellerie Y., Maillet N., Maneux E., Etcheber H. (2002). TenYear-Observation of the Gironde Fluvial System: Fluxes of Suspended Matter, Particulate Organic Carbon and Cadmium. Marine Chemistry 79, 229-242.

Sen, I.S., Peucker-Ehrenbrinck, B., 2012. Anthropogenic disturbance of element cycles at the Earth's surface. Environmental Science and Technology 46, 8601-8609. Shams, L., Turner, A., Millward, G.E., Brown, M.T., 2014. Extra-and intra-cellular accumulation of platinum group elements by the marine microalga, Chlorella stigmatophora. Water Research 50, 432-440. 
Sottolichio, A., Castaing, P., 1999. A synthesis on seasonal dynamics of highly concentrated structures in the Gironde Estuary. Comptes Rendus de l'Academie de Sciences, Sciences de la Terre et des Planetes 329, 795-800.

Soyol-Erdene, T.O., Huh, Y., Hong, S., Hur, S.D., 2011. A 50-year record of platinum, iridium, and rhodium in antarctic snow: volcanic and anthropogenic sources. Environmental Science and Technology 45, 5929-5935.

Soyol-Erden, T.E., Huh, Y., 2012. Dissolved platinum in major rivers of East Asia: implications for the oceanic budget. Geochemistry Geophysics Geosystems 13, Q06009.

Tuit, C.B., Ravizza, G.E., Bothner, M.H., 2000. Anthropogenic platinum and palladium in sediments of Boston Harbor. Environmental Science and Technology 34, 927-932.

Turner, A., 2007. Particle-water interactions of platinum group elements under simulated estuarine conditions. Marine Chemistry 103, 103-111.

Turner, A., Mascorda, L., Particle-water interactions of platinum-based anticancer drugs in river water and estuarine water. Chemosphere (in press).

Turner, A., Millward, G.E., 2002. Suspended particles - their role in estuarine biogeochemical cycles. Estuarine and Coastal Shelf Science 55, 857-883.

Turner, A., Crussell, M., Millward, G.E., Cobelo-Garcia, A., Fisher, A.S., 2006. Adsorption kinetics of platinum group elements in river water. Environmetnal Science and Technology 40, 1524-1531.

United Nations (UN), Population Division, 2007. World Urbanization Prospects: The 2007 Revision. U.N. New York.

Van den Berg, C.M.G., Jacinto, G.S., 1988. The determination of platinum in sea water by adsorptive cathodic stripping voltammetry. Analytica Chimica Acta 211, 129-139. Verstraete, S., Heudi, H., Cailleux, A., Allain, P., 2001. Comparison of the reactivity of oxaliplatin, Pt(diaminocyclohexane)Cl2 and Pt(diaminocyclohexane)(OH2)22+ with guanosine and L-methionine. Journal of Inorganic Biochemistry 84, 129-135. 
Figure Captions

Figure 1. Map of the Gironde Estuary and fluvial reaches of the Garonne and Dordogne Rivers, with sampling points along the salinity gradient $(K P>20)$ and at La Réole ( $K P=$ $-70)$

Figure 2. Figure 2. Variation of $P t_{D}(<0.2 \mu m)$ during estuarine mixing for the November 2012 (a) and March 2013 (b) sampling dates. Theoretical dilution lines are shown adjoining the dissolved river end-member concentrations and the average dissolved Pt concentration in the North Atlantic (open symbol) from Colodner (1991). The irregular solid lines represent the distributions of suspended particulate matter.

Figure 3. Variation of (a) $\mathrm{Pt}_{\mathrm{p}}(>0.2 \mu \mathrm{m})$, (b) particle-water distribution coefficients and (c) enrichment factors (EF) during estuarine mixing for the November 2012 (closed circles) and March 2013 (open circles) estuarine samplings. Also included are data for the J anuary 2013 river sampling (squares) and March 2007 bottom SPM sampling (open triangles). Enrichment factors were calculated using equation 2; see text for further information.

Figure 4. Figure 4: Fractionation of Pt in the Gironde Estuary (November, $\mathbf{\square}$; March, $\mathbf{\Delta}$ ) and in the Lérez Estuary (April 2008, ○; May 2013, $\diamond$ ) as a function of the concentration of suspended particulate matter, SPM, and as calculated according to equation 2. 
Table 1. Salinities, concentrations of suspended particulate matter (SPM), dissolved Pt and particulate $\mathrm{Pt}\left(\mathrm{Pt}_{\mathrm{D}}\right.$ andPt $t_{\mathrm{P}}$, respectively), and $\mathrm{Th}_{\mathrm{P}}$ concentrations and $\mathrm{Pt}$ enrichment factors $\left(\mathrm{EF}_{\mathrm{Pt}}\right)$ in the Gironde system.

\begin{tabular}{|c|c|c|c|c|c|c|c|}
\hline & & $\begin{array}{l}\text { SPM } \\
\left(\mathrm{mg} \mathrm{L}^{-1}\right)\end{array}$ & $S$ & $\begin{array}{l}\mathrm{Pt}_{\mathrm{D}} \\
(\mathrm{pM})\end{array}$ & $\begin{array}{l}\mathrm{Pt}_{\mathrm{P}} \\
\left(\mathrm{pmol} \mathrm{g}^{-1}\right)\end{array}$ & $\begin{array}{c}\mathrm{Th}_{\mathrm{P}} \\
\left(\mu \mathrm{mol} \mathrm{g}{ }^{-1}\right)\end{array}$ & $\mathrm{EF}_{\mathrm{Pt}}$ \\
\hline \multicolumn{8}{|l|}{$\begin{array}{l}\text { River samples } \\
\text { (surface SPM) }\end{array}$} \\
\hline \multirow[t]{2}{*}{ January 2013} & Port St Marie & 163 & 0.0 & 0.53 & 3.74 & & \\
\hline & La Réole & 168 & 0.0 & 0.53 & 3.64 & 0.0562 & 1.16 \\
\hline \multicolumn{8}{|c|}{$\begin{array}{l}\text { Estuarine samples } \\
\text { (Surface SPM) }\end{array}$} \\
\hline \multirow[t]{15}{*}{ November 2012} & & 2373 & 1.2 & 0.51 & 3.13 & 0.0537 & 1.03 \\
\hline & & 253 & 2.7 & 0.58 & 3.43 & 0.0455 & 1.33 \\
\hline & & 272 & 3.6 & 0.63 & 3.28 & & \\
\hline & & 424 & 5.4 & 0.84 & 4.31 & 0.0471 & 1.61 \\
\hline & & 180 & 7.6 & 0.74 & 3.33 & & \\
\hline & & 254 & 8.4 & 0.57 & 4.51 & & \\
\hline & & 164 & 9.9 & 0.66 & 8.97 & 0.0545 & 2.91 \\
\hline & & 275 & 11.5 & 0.40 & 3.02 & & \\
\hline & & 103 & 13.2 & 0.55 & 4.77 & & \\
\hline & & 222 & 15.0 & 0.51 & 5.13 & & \\
\hline & & 94 & 17.2 & 0.35 & 4.36 & 0.0420 & 1.83 \\
\hline & & 91 & 21.2 & 0.61 & 1.95 & 0.0447 & 0.76 \\
\hline & & 48 & 24.3 & 0.43 & 2.51 & & \\
\hline & & 48 & 27.0 & 0.39 & 1.03 & & \\
\hline & & 21 & 28.1 & 0.39 & 1.44 & & \\
\hline \multirow[t]{11}{*}{ March 2013} & & 93 & 0.2 & 0.60 & 5.18 & & \\
\hline & & 664 & 0.5 & 0.46 & 1.28 & 0.0554 & 0.41 \\
\hline & & 832 & 0.9 & 0.49 & 1.28 & 0.0493 & 0.46 \\
\hline & & 849 & 2.6 & 0.51 & 2.36 & 0.0480 & 0.87 \\
\hline & & 293 & 6.3 & 0.41 & 4.97 & & \\
\hline & & 130 & 9.4 & 0.46 & 4.36 & & \\
\hline & & 414 & 10.8 & 0.50 & 3.08 & 0.0544 & 0.99 \\
\hline & & 169 & 12.0 & 0.47 & 4.36 & 0.0449 & 1.71 \\
\hline & & 91 & 16.9 & 0.62 & 2.87 & 0.0462 & 1.09 \\
\hline & & 149 & 17.9 & 0.45 & 4.15 & & \\
\hline & & 85 & 22.7 & 0.53 & 4.56 & & \\
\hline \multicolumn{8}{|l|}{$\begin{array}{l}\text { Estuarine samples } \\
\text { (bottom SPM) }\end{array}$} \\
\hline \multirow[t]{9}{*}{ March 2007} & & 1640 & 0.0 & & 2.61 & 0.0397 & 1.16 \\
\hline & & 23600 & 0.4 & & 1.69 & 0.0493 & 0.61 \\
\hline & & 59300 & 3.8 & & 3.08 & 0.0470 & 1.16 \\
\hline & & 32200 & 4.8 & & 2.87 & 0.0519 & 0.98 \\
\hline & & 4300 & 7.4 & & 4.36 & 0.0445 & 1.73 \\
\hline & & 51400 & 6.9 & & 2.92 & 0.0440 & 1.17 \\
\hline & & 66100 & 8.5 & & 4.46 & 0.0646 & 1.22 \\
\hline & & 22100 & 13.1 & & 2.97 & 0.0522 & 1.00 \\
\hline & & 134 & 21.6 & & 2.36 & 0.0532 & 0.78 \\
\hline
\end{tabular}


Click here to download high resolution image

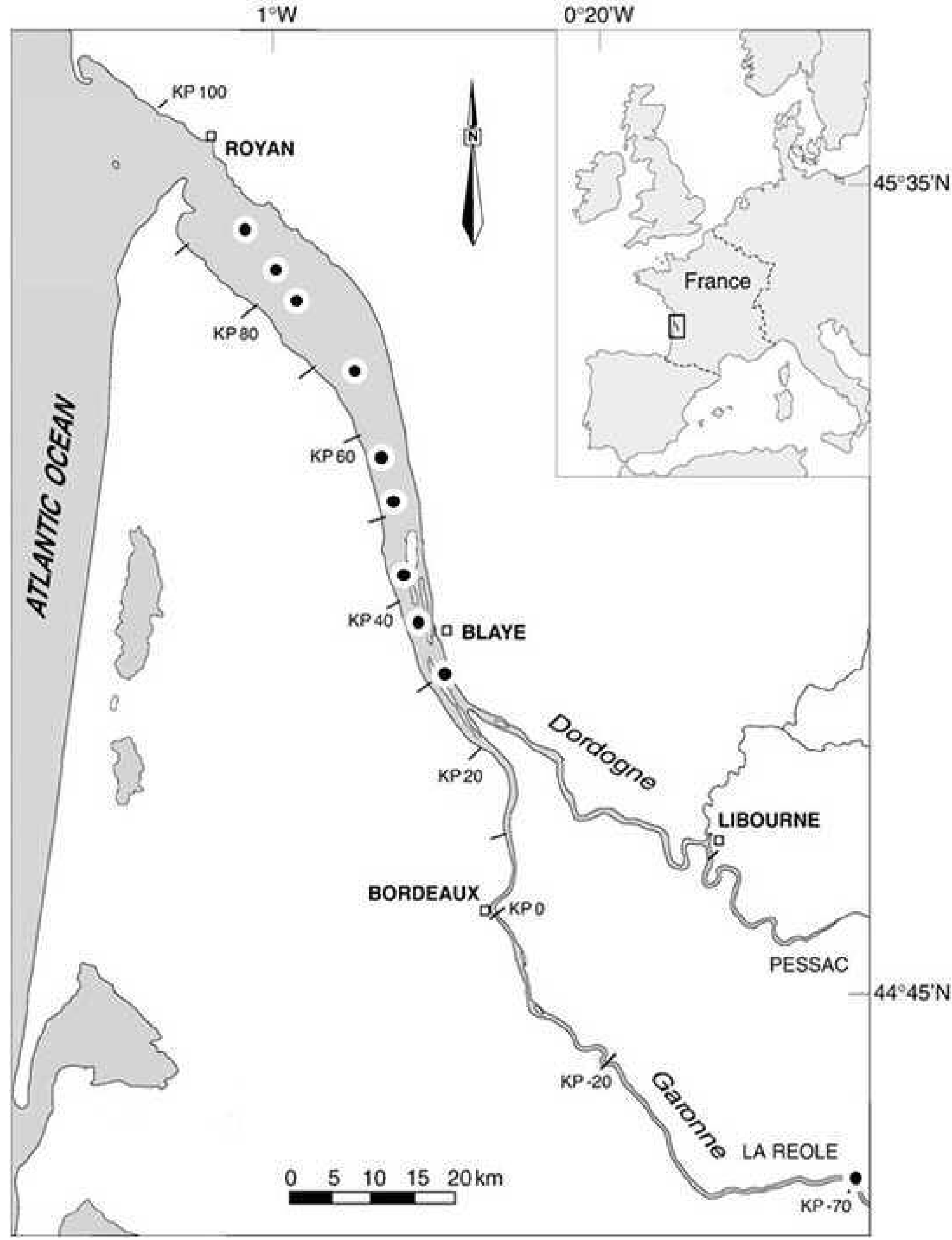



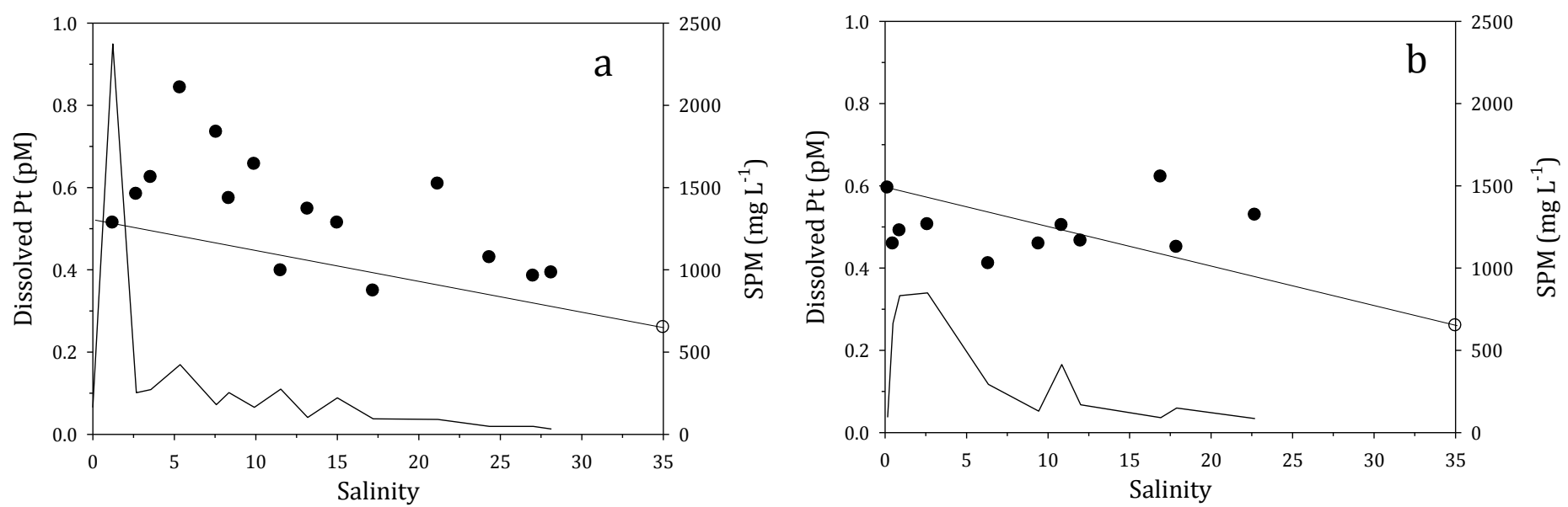

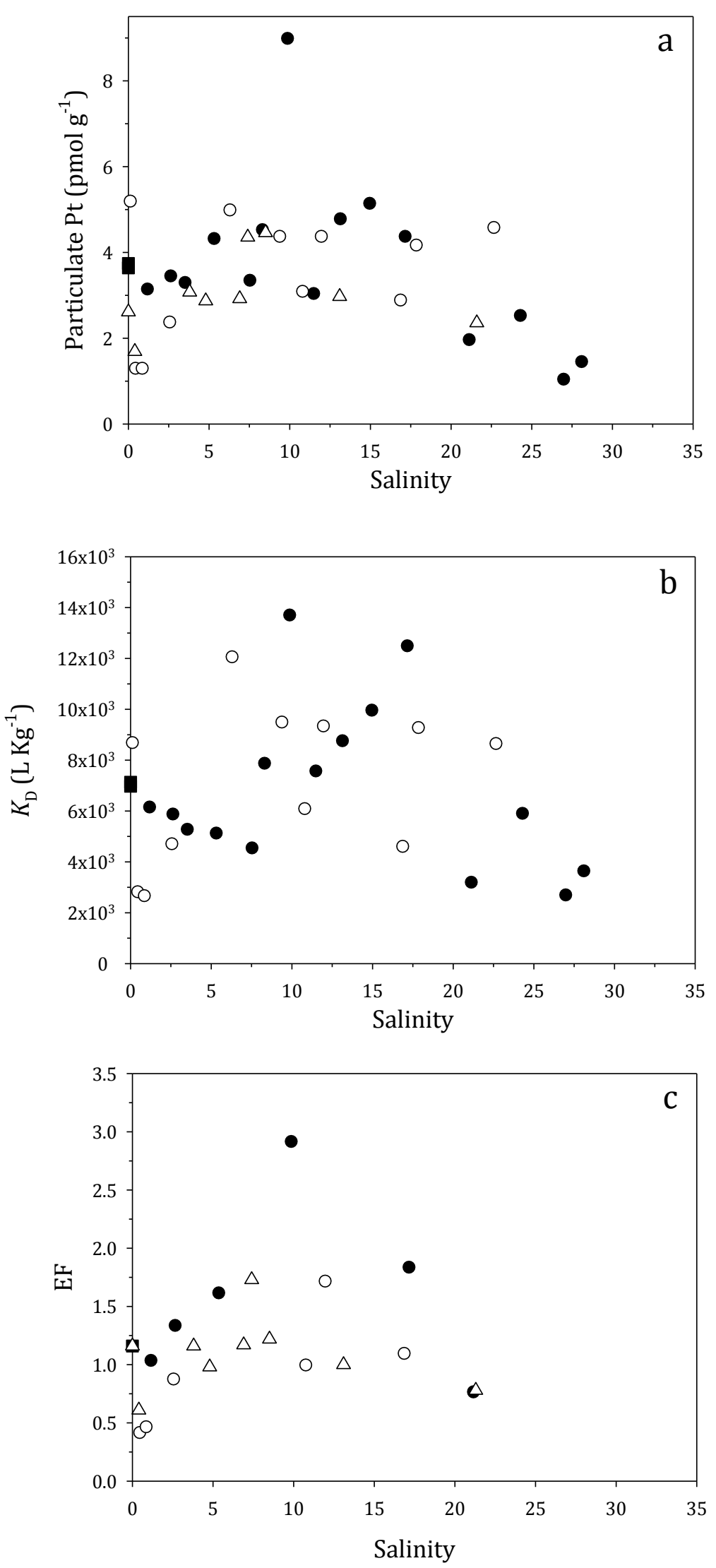


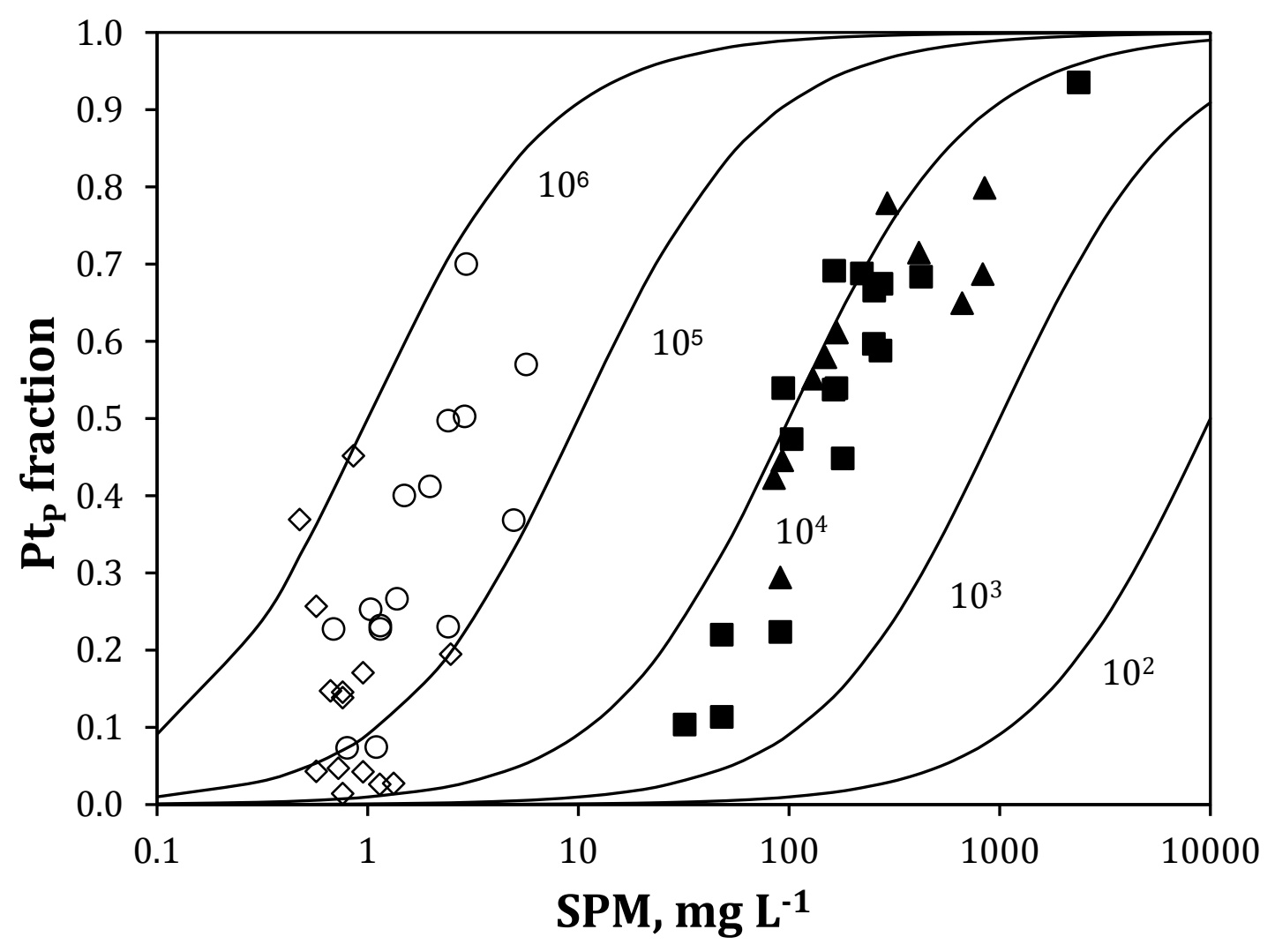




\section{Highlights}

- $\quad$ Dissolved and particulate platinum have been measured along the salinity gradient in surface water of the Gironde Estuary

- $\quad$ Dissolved and particulate platinum concentrations displayed maxima but at different locations along the salinity gradient

- $\quad$ No clear trend for particle-water distribution coefficients was evident

- Estuarine reactivity is of major importance for both the distributions of Pt in estuaries and its export to the global ocean 